\title{
FOREIGN ECONOMIC ACTIVITIES OF UKRAINE: REGIONAL FEATURES, TRENDS AND DIRECTIONS FOR DEVELOPMENT
}

Target setting. The development of foreign economic relations is a very important task of the state. The realization of such a task contributes to the economic growth of the country and regions, and to improving the standard of living of the population. Foreign economic activity is an essential component of the country's economy, so its activation and strengthening in the regions is a priority direction of the state's economic development strategy.

The development of foreign economic relations of regions leads to an increase in the amount of tax revenues to local budgets according to the change of their sources in the conditions of decentralization reform. Thus, according to this reform, $50 \%$ of the amount of excess of the monthly indicators of customs payments received by the respective regional customs of the State Fiscal Service is credited to local budgets [1]. Such state policy, carried out in the framework of reforming local self-government and territorial organization of power in Ukraine [2], encourages the motivation for the regions development and their foreign economic activity, attracting investments to local budgets, and the amount of financial revenues create an opportunity for economy successful development of regions and the state.

Recent research and publications analysis. The research of foreign economic activity of the regions of Ukraine is devoted to numerous works of leading domestic scientists. In recent years the issue has been actualized in the writings of V. Hoblyk [3], E. Zabarna [4], M. Karpiak [5], V. Chernyshev [6]. The analysis of the main economic indicators of the foreign economic activity of the regions in recent years clearly shows the changes that have occurred in the total volumes, commodity structure and geographical directions of foreign trade and the factors that caused them. The outlined issues of the prevalence of low-cost (commodity) goods during export over highly liquid imported goods characterize the generally unsatisfactory state of economic development efficiency and point to the low competitiveness of domestic producers in the world market. According to scientists' opinions, the modernization of the economy of Ukraine, in particular of industrial regions in the conditions of decentralization of management [7;
8], the direction that will ensure the structural restructuring of production, improving the quality of goods produced in the regions, the growth of a developed economy of the state.

Ukrainian and international experts analyze and monitor key economic and political processes and provide comprehensive support to the Cabinet of Ministers of Ukraine. Thus, many institutions are currently dealing with decentralization issues, including The Center for Political and Legal Reforms is a non-governmental organization providing analytical support; the portal «Decentralization», created on the initiative of the Ministry of Development of Communities and Territories; VoxUkraine - an independent analytical platform where highly qualified economists and lawyers exercise their activities; The Reform Office is an organization that is part of an innovative Ukrainian Reform Architecture, created on the joint initiative of the European Union and the European Bank for Reconstruction and Development.

The strategic changes that have taken place in the reorientation of the global course of the national economy development to European and world markets have challenged the established partnerships that have existed for years between the industrial enterprises of the regions and their foreign economic partners. Therefore, an urgent scientific task is to study the processes of stimulating foreign economic activity development at the regional level and to develop appropriate mechanisms.

The purpose of the article is to substantiate the contemporary features and tendencies in the foreign economic activity sphere of economic regions of Ukraine and to develop proposals for directions of their development.

Research findings. At present, Ukraine has 24 oblasts in its administrative structure and is the largest in Europe in terms of its temporarily non-controlled territories. Due to the heterogeneity of natural resources, population, structure of economy, regions are conditionally united in 9 economic regions: Donetsk (Donetsk, Luhansk oblasts), Pridneprovskyi (Dnipropetrovsk, Zaporizhzhya oblasts), Northeast (Kharkiv, Sumy, Poltava oblasts), Central (Cherkasy, Kirovohrad oblasts), North- 
western (Volyn, Rivne oblasts), Podilskyi (Vinnytsia, Ternopil, Khmelnytskyi oblasts), the Black Sea (Mykolaiv, Odesa, Kherson oblasts), and also annexed to present-day Crimea), the Carpathian (Transcarpathian, Lviv, Ivano-Frankivsk, Chernivtsi oblasts), the Capital region (Kyiv, Zhytomyr, Chernihiv oblasts).

Economic regions differ in their industrial specialization, which has been influenced by many factors, including such as natural conditions, geographical location, population, economic potential. By specialization, they are conventionally divided into industrial and agricultural regions, which in turn are divided by profile. Thus, in Donetsk and Pridneprovskyi regions electricity, metallurgy, fuel and chemical industries, machine building are more developed. In the North-East and the Black Sea regions, besides the fuel industry, mechanical engineering, light and food industries have been developed. Central, Podil, North-West and Carpathian regions specialize in mechanical engineering, forestry, agriculture, wood processing and food industry. Due to the close interaction between them, they make up the single economic complex of Ukraine. Currently, due to some actions on the part of the Russian Federation, Donetsk and the Black Sea regions have lost their industry share, reduced economic potential, and therefore have to rebuild their economic ties and seek new trading partners.
The technical rally of foreign economic activity and its strengthening in the regions is the basis for the national economy development, and therefore the Program of Development of Ukrainian Exports has been identified as one of the priorities for the Sustainable Development Strategy «Ukraine 2020» implementation [9], which is an instrument for transformation in the country under the concluded Agreement on association between Ukraine and the European Union [10]. Regions are independent subjects of market relations, where the goals and objectives of socio-economic development are directly realized, in which the region competitiveness is essential. In the context of globalization, the region competitiveness is the willingness to respond to the global environmental challenges, the ability to adapt to changing conditions, to find and protect local competitive advantages, to support or improve the position of the region's economy in global competition [11].

Based on the foreign trade volume in goods and services in 2018, the most significant volumes of imports and exports are in the Capital and Pridneprovskyi regions (Fig. 1). However, their focus is different. Import-oriented ones are the three regions - Metropolitan, Carpathian, Northwestern, and export-oriented are the six other regions, with Prydniprovskyi and Donetsk having the biggest difference between exports and imports.

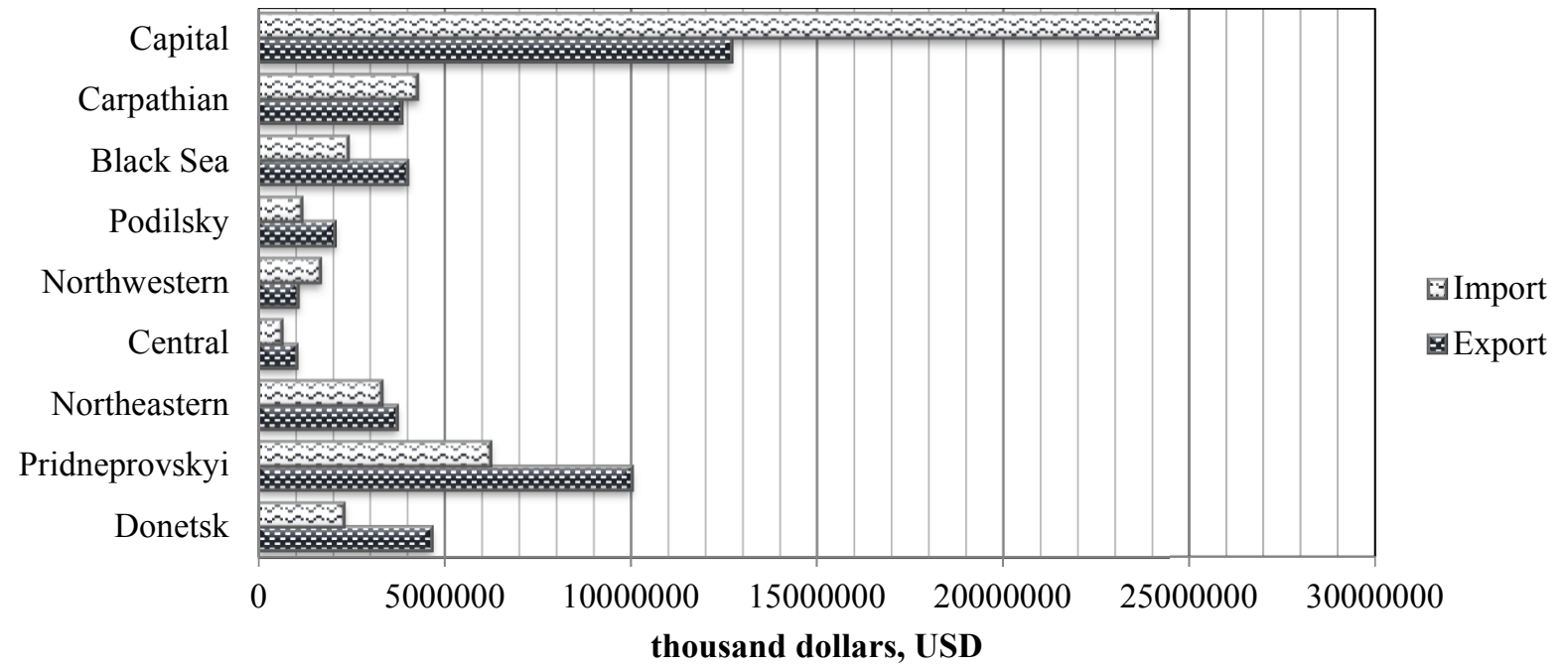

Fig. 1. Exports and imports by economic regions of Ukraine in 2018

Source: Compiled by the authors according to the State Statistics Committee of Ukraine (since 2015 without taking into account the temporarily occupied territory of the Autonomous Republic of Crimea, the city of Sevastopol and parts of the temporarily occupied territories in Donetsk and Luhansk oblasts) [12].

The analysis of the foreign economic activity of the regions was carried out according to the main analytical indicators - growth rates, changes in product structure and geographical directions, which were calculated according to generally accepted formulas [13]. Thus, the growth rate $(\mathrm{Gr})$ was calculated by the formula:

$$
\mathrm{Gr}=\frac{C_{1}-P_{o}}{P_{o}}
$$

where $C_{1}$ - volume of the current period,

$P_{0}-$ volume of the previous period.

The calculations depicted (Table 1) that the growth rates are different by economic regions and in time. 
Thus, in 2014, in relation to 2013 from exportoriented regions, only North-West and Podilskyi show positive growth rates, but they are insignificant - from 4 to $5 \%$. Other regions have negative growth rates, with the largest in Donetsk and the Black Sea regions. This is due to the military conflict that began in eastern Ukraine and the annexation of Crimea. Similarly, the political events that took place in the capital during the same period also affected the foreign economic volumes of the Capital Region - exports fell by $78 \%$ and imports - by
34\%. In 2017 and 2018, export growth rates are positive for both export-oriented and import-oriented regions. Of the export-oriented regions, Podillya and Pridneprovskyi have the highest rates, but an import-oriented region such as the Carpathian one also exhibits high growth rates of exports - more than $20 \%$, though smaller, albeit slightly, than in imports. The negative dynamics of the export growth rate continued throughout 2015-2016 and only since 2017 has become positive in all regions.

The growth rate of exports and imports of goods by region in 2014-2018 (\%)

\begin{tabular}{|c|c|c|c|c|c|}
\hline Region & $\begin{array}{c}\text { Growth rate, } \\
2014 / 2013\end{array}$ & $\begin{array}{c}\text { Growth rate, } \\
2015 / 2014\end{array}$ & $\begin{array}{c}\text { Growth rate, } \\
2016 / 2015\end{array}$ & $\begin{array}{c}\text { Growth rate, } \\
2017 / 2016\end{array}$ & $\begin{array}{c}\text { Growth rate, } \\
2018 / 2017\end{array}$ \\
\hline \multicolumn{6}{|c|}{ Export } \\
\hline Donetsk & -36.25 & -60.88 & -2.19 & 20.69 & 8.18 \\
\hline Pridneprovskyi & -7.27 & -25.32 & -12.57 & 23.00 & 10.63 \\
\hline Northeastern & -15.85 & -27.43 & -11.57 & 24.04 & 6.92 \\
\hline Central & -11.25 & -41.81 & 7.26 & 14.60 & 26.52 \\
\hline Northwestern & 4.25 & -12.83 & -7.91 & 15.32 & 5.43 \\
\hline Podilsky & 4.83 & -4.23 & 3.67 & 29.43 & 22.00 \\
\hline Black Sea & -23.11 & -10.27 & -3.80 & 16.61 & 1.18 \\
\hline Carpathian & 3.67 & -15.82 & 14.33 & 20.95 & 20.26 \\
\hline Capital & -78.48 & 243.00 & -2.06 & 13.49 & 6.45 \\
\hline \multicolumn{6}{|c|}{ Import } \\
\hline Donetsk & -46.82 & -51.55 & -3.48 & 57.18 & 9.73 \\
\hline Pridneprovskyi & -12.52 & -30.66 & 3.05 & 40.43 & 12.66 \\
\hline Northeastern & -12.32 & -29.27 & 10.63 & 19.90 & 15.10 \\
\hline Central & -16.46 & -46.04 & 42.49 & 34.53 & 3.41 \\
\hline Northwestern & -26.01 & -21.37 & 68.08 & 20.96 & -0.53 \\
\hline Podilsky & -18.89 & -27.20 & 15.38 & 29.45 & 21.79 \\
\hline Black Sea & -50.00 & -41.89 & 23.80 & 15.72 & 8.45 \\
\hline Carpathian & -11.99 & -40.99 & 17.73 & 28.13 & 21.62 \\
\hline Capital & -34.00 & -17.13 & 12.37 & 21.35 & 16.76 \\
\hline
\end{tabular}

Source: Compiled by the authors according to the State Statistics Committee of Ukraine (since 2015 without taking into account the temporarily occupied territory of the Autonomous Republic of Crimea, Sevastopol and part of the temporarily occupied territories in Donetsk and Luhansk regions) [12].

Import growth rates in 2014 and 2015 were negative in all regions and changed to positive since 2016 with few exceptions (in Donetsk region in 2016, in the Northwest in 2018). Attention has to be paid to the fact that the highest growth rates of imports are in exportoriented regions: Northwestern - in 2016, Donetsk and Pridneprovskyi - in 2017. In 2018, the growth rates of imports decreased compared to 2017 and were the highest in the Carpathian region as an import-oriented region, as well as in the Podilsk region as an export-oriented one.

Another indicator for determining trends in the foreign economic activity development in the regional aspect is the indicator of absolute growth. It is calculated by evaluating baseline data for the current and base periods. The values of absolute growth were determined by two methods [13]. According to the first, basic method, the baseline absolute increment for each year $\left(\Delta \mathrm{Y}_{\mathrm{b}}\right)$ was calculated by the formula:

$$
\Delta Y_{b}=Y_{i}-Y_{0},
$$

where $Y_{i}$ - value of the increase in the comparison period,

$$
Y_{0} \text { - base period of increment value. }
$$

By the second, linear method, the chain absolute increment for each year $(\Delta \mathrm{Yi})$ was calculated by the formula:

$$
\Delta Y_{l}=Y_{i}-Y_{i-1},
$$

where $Y_{i-1}$ - value of the increase of the previous period.

According to the calculated data (Table 2), in 2017, none of the regions achieved the level of basic absolute growth in both exports and imports, which were noted in 2013. Changes in the national political and economic course, a sharp fall in the national currency against the 
US dollar (almost three times), lost existing markets of the Commonwealth of Independent States, and not fully functioning new European agreements made the year 2015 the most difficult for the economy. All regions deteriorated, including in relation to the last year.

Further ratification of the Free Trade Agreement between Ukraine and the EU in the second half of 2016, as well as the entry of state agrarians into European markets, relative stabilization of the exchange rate, lower inflation and a gradual increase in gross domestic trade, led to a revival of international trade in all regions, but indicators did not reach the levels of 2013. The most stable growth during the 2016-2017 years was noted for the Donetsk and Pridneprovskyi regions. The sharp fluctuations in Capital Region indicators at that time did not have a stable tendency for the imports and exports development. This is due to the fact that many enterprises of Donetsk, Luhansk and Crimea have temporarily moved their production and industrial bases to the Capital Region, transport corridors, places of administration of customs payments had been changed. This is confirmed by the fact that such an increase was one-off, and in 2016 the export and import chain absolute growth in the Capital Region was the most negative in Ukraine, and in 2017 the indicator showed a slight increase.

Absolute increase in exports and imports of goods by region in 2014-2017 (\%)

\begin{tabular}{|c|c|c|c|c|c|c|c|c|}
\hline \multirow[b]{2}{*}{ Region } & \multicolumn{2}{|c|}{2014} & \multicolumn{2}{|c|}{2015} & \multicolumn{2}{|c|}{2016} & \multicolumn{2}{|c|}{2017} \\
\hline & 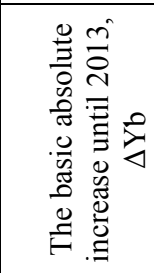 & 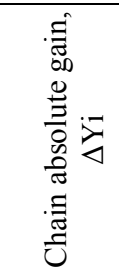 & 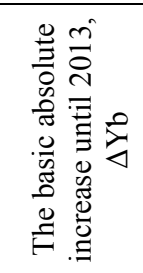 & 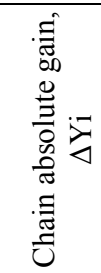 & 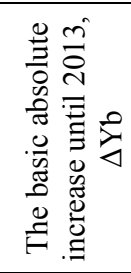 & 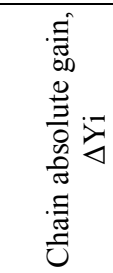 & 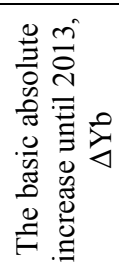 & 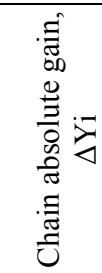 \\
\hline \multicolumn{9}{|c|}{ Export } \\
\hline Donetsk & -136.25 & -136.25 & -160.88 & -24.63 & -102.19 & 58.69 & -79.31 & 22,88 \\
\hline Pridneprovskyi & -107.27 & $-107,27$ & -125.32 & -18.05 & -112.57 & 12.76 & -77.00 & 35,56 \\
\hline Northeastern & -115.85 & -115.85 & -127.43 & -11.58 & -111.57 & 15.86 & -75.96 & 35,61 \\
\hline Central & -111.25 & -111.25 & -141.81 & -30.56 & -92.74 & 49.07 & -85.40 & 7,34 \\
\hline Northwestern & -95.75 & -95.75 & -112.83 & -17.08 & -107.91 & 4.93 & -84.68 & 23,22 \\
\hline Podilsky & -95.17 & -95.17 & -104.23 & -9.07 & -96.33 & 7.90 & -70.57 & 25,76 \\
\hline Black Sea & -123.11 & -123.11 & -110.27 & 12.84 & -103.80 & 6.47 & -83.39 & 20,41 \\
\hline Carpathian & -96.33 & -96.33 & -115.82 & -19.49 & -85.67 & 30.15 & -79.05 & 6,62 \\
\hline Capital & -178.48 & -178.48 & 143.00 & 321.47 & -102.06 & -245.05 & -86.51 & 15,55 \\
\hline \multicolumn{9}{|c|}{ Import } \\
\hline Donetsk & -146.82 & -146.82 & -151.55 & -4.73 & -103.48 & 48.07 & -42.82 & 60.66 \\
\hline Pridneprovskyi & -112.52 & -112.52 & -130.66 & -18.14 & -96.95 & 33.71 & -59.57 & 37.38 \\
\hline Northeastern & -112.32 & -112.32 & -129.27 & -16.95 & -89.37 & 39.9 & -80.1 & 9.27 \\
\hline Central & -116.46 & -116.46 & -146.04 & -29.58 & -57.51 & 88.53 & -65.47 & -7.96 \\
\hline Northwestern & -126.01 & -126.01 & -121.37 & 4.64 & -31.92 & 89.45 & -79.04 & -47.12 \\
\hline Podilsky & -118.89 & -118.89 & -127.2 & -8.31 & -84.62 & 42.58 & -70.55 & 14.07 \\
\hline Black Sea & -150 & -150 & -141.89 & 8.11 & -76.2 & 65.69 & -84.28 & -8.08 \\
\hline Carpathian & -111.99 & -111.99 & -140.99 & -29 & -82.27 & 58.72 & -71.87 & 10.40 \\
\hline Capital & -134.0 & -134.0 & -117.13 & 16.87 & -87.63 & 29.5 & -78.65 & 8.98 \\
\hline
\end{tabular}

Source: Compiled by the authors according to the State Statistics Committee of Ukraine (since 2015 without taking into account the temporarily occupied territory of the Autonomous Republic of Crimea, Sevastopol and part of the temporarily occupied territories in Donetsk and Luhansk regions) [12].

In order to objectively assess the state of international trade in the regions, one has to consider its product structure. The Standard International Trade Classification (SITC) of the United Nations Conference on Trade and Development (UNCTAD) was used to analyze the commodity structure [14]. According to the classification 225 categories of goods, according to different categories as for compatibility of different skills, technologies and capital intensity, are divided into several groups:

A - main products of consumption, food;

B - labour-intensive and resource-intensive production;
$\mathrm{C}$ - production with a low level of qualification and technological intensity;

$\mathrm{D}$ - production with average qualification level and average technological intensity;

$\mathrm{E}$ - productions that use highly skilled labour and have a high technological level;

$\mathrm{F}$ - unclassified goods.

Consequently, products of categories $\mathrm{A}$ and $\mathrm{F}$ can be divided into separate groups. The products of crop and livestock production, whose production depends on the geographical location of the regions, natural factors and does not require a high level of skills of workers, are mainly in category A. These are so-called consumption 
products that satisfy the individual needs of the population. Category $\mathrm{F}$ is a single, low-value item, including single, high-value antiques and artwork. Categories B, $\mathrm{C}, \mathrm{D}, \mathrm{E}$ belong to the other product groups, which are a set of production products and are intended to participate in production processes that are distributed in order of their industrial purpose increase - from simple, lowefficiency and high-cost production to goods in need of high level of technology and skilled workers for their production, so-called high-tech goods. A number of high value-added goods characterize the state of economic development efficiency. The prevalence of such goods in exports indicates the competitiveness of manufacturers in the world market.

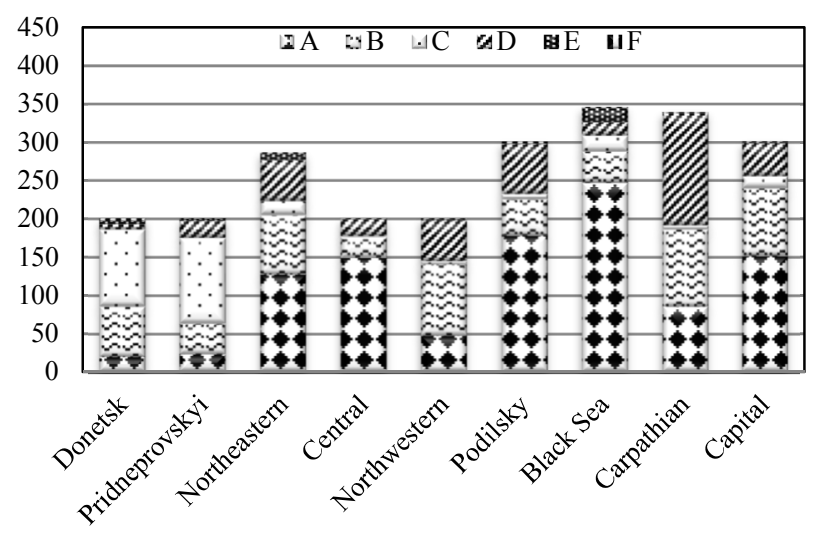

$a$
The established commodity structure of exports and imports of goods by region shows (Fig. 2) that in the export of most regions, with the exception of Donetsk and Prydniprovsky, commodities of category A are predominant, which are mostly low value-added goods, are seasonal and naturally dependent - climatic factors. The largest share in all regions is made up of products of category B - labour-intensive and resource-intensive, environmentally dangerous industries. The commodity structure of imports of goods is quite the opposite. All regions are actively purchasing finished products of category B and D, among which consumer goods clothing, electrical goods, surfactants, detergents, various chemical products prevail. The volume of imported ground transport vehicles (category E) - goods that are almost not produced in Ukraine - are significant.

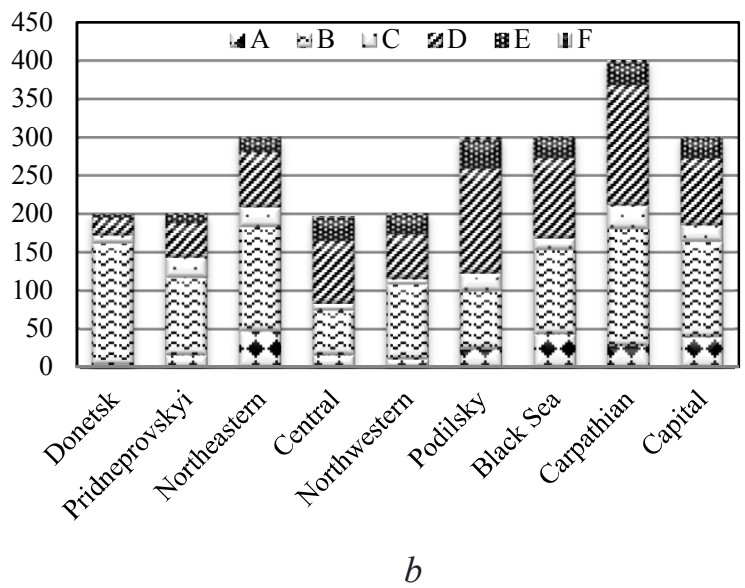

Fig. 2. Commodity structure of exports (a) and imports (b) by region

Source: Compiled by the authors.

The obtained data on the structure of foreign trade show considerable technical backwardness of the production of the regions. High value-added goods form the basis of imports, while high-cost and low-performing goods dominate exports. The prevalence of such goods in exports indicates low economic efficiency and low competitiveness of domestic producers. Structural restructuring of production, improving the quality of commodities produced by regions is the way to a developed economy of the state.

Conclusions. As a result of the research, modern features and tendencies in the sphere of foreign economic activity of economic regions of Ukraine have been scientifically substantiated. Most economic regions are found to be export-oriented - six out of nine. However, the export potential is not fully realized: the economic regions show positive growth in exports only from 2017, while in imports - since 2016. Moreover, the highest growth rates of imports are in export-oriented regions. In 2018, the growth rate of imports decreased. In 2017 , none of the regions achieved the baseline abso- lute increase in both exports and imports noted in 2013. By commodity structure, according to the international classification, in the export of most regions, with the exception of Donetsk and Prydniprovsky, raw materials of category A with small added value prevail, and the greater share in all regions is represented by goods of category B - labour-intensive and resource-intensive, environmentally dangerous industries. The situation in the commodity structure of imports of goods is the opposite. All regions actively import finished goods of category B and D, and volumes of means of land transport - goods of category E are also significant.

In order to restore Ukraine's status as an export-oriented state, it is necessary, above all, to provide the following instruments in the economic development mechanism:

development and further implementation according to clear indicators of Export Development Programs by economic regions;

development of a strategy of competitiveness of Ukraine in the global world, and on the basis of it - spe- 
cific programs for economic regions, coordinated with export development programs;

creation of a favorable institutional environment for business development, support of its competitive strategies for the formation of certain competitive advantages for regional business;

use of public-private partnerships for specific programs and business plans aimed at increasing export potential and import substitution.

The use of such tools will eliminate the imbalances in the socio-economic development of regions and the state as a whole.

\section{Literature}

1. Про проведення експерименту з фінансового забезпечення здійснення заходів з розвитку автомобільних доріг загального користування, ділянок вулиць $\mathrm{i}$ доріг міст та інших населених пунктів, що суміщаються $з$ автомобільними дорогами загального користування, в усіх областях та м. Києві, а також дорожньої інфраструктури у м. Києві: Постанова Кабінету Міністрів України від 16.09.2015 p. № 726. URL: https://zakon.rada.gov.ua/laws/show/726-2015-П. 2. Концепція реформування місцевого самоврядування та територіальної організації влади в Україні: Розпорядження Кабінету Міністрів України від 1 квітня 2014 р. № 333-p. URL: https://zakon.rada.gov.ua/laws/show/3332014-p. 3. Гоблик В. В. Механізм становлення зовнішньоекономічних зв'язків у транскордонних регіонах в умовах європейської інтеграції України. Моделі і механізми регулювання єврорегіонального співробітництва України: монографія / за заг. ред. І. В. Артьомова. Ужгород: МПП «Гражда», 2013. 156 с. 4. Забарна Е. М. Інституційний фактор розвитку регіональних зовнішньоекономічних зв'язків в Україні. Економіка: реалї часy. 2015. № 1 (17). C. 30-34. URL: http://economics. opu.ua/files/archive/2015/n1.html. 5. Карп'як М. О., Попадинець Н. М. Зовнішньоекономічна діяльність регіонів України в умовах російської агресії: структурні особливості. Регіональна економіка. 2016. № 1. С. 51-58. 6. Чернишев В. Г., Окара Д. В., Ковальова І. Л. Зовнішньоекономічна діяльність регіонів України. Ефективна економіка. 2019. № 6. URL: http: //www.economy.nayka.com.ua/pdf/6_2019/55.pdf. doi: 10.32702/2307-2105-2019.6.53. 7. Перший етап модернізації економіки України: досвід та проблеми / O.M. Алимов, О.І. Амоша та ін.; за заг. ред. В.І. Ляшенка. Запоріжжя: КПУ, 2014. 798 с. 8. Модернізація економіки промислових регіонів України в умовах децентралізації управління: монографія / O.І. Амоша, Ю.М. Харазішвілі, В.І. Ляшенко та ін. Київ: Ін-т економіки промисловості, 2018. 300 с. 9. Стратегія сталого розвитку «Україна - 2020»: Указ Президента України від 12 січня 2015 року № 5/2015. URL: https://zakon.rada.gov.ua/ laws/show/5/2015. 10. Угода про асоціацію між Україною, з однієї сторони, та Свропейським Союзом, Свропейським співтовариством 3 атомної енергії і їхніми державами-членами, 3 іншої сторони: Закон україни від 16.09.2014 р. № 1678-VII. URL: https: //zakon. rada.gov.ua/laws/show/984_011. 11. Лемдяев А. В. Конкурентоспособность: региональный вектор. Управление экономическими системами. 2010. № 2 (22). С. 5458. 12. Офіційний сайт Державної фіскальної служби України. URL: http://sfs.gov.ua (дата звернення 10.11.2019). 13. Білецька Л. В., Білецький О. В., Савич В. І. Економічна теорія (Політекономія. Мікроекономіка. Макроекономіка): навч. посіб. 2-ге вид. перероб. та доп. Київ: Центр учбової літератури, 2009. C. 242-247. 14. Trade and development report. United Nations, 2002 URL: https://unctad.org/en/Docs/tdr2002_ en.pdf.

\section{References}

1. Pro provedennia eksperymentu $\mathrm{z}$ finansovoho zabezpechennia zdiisnennia zakhodiv $\mathrm{z}$ rozvytku avtomobilnykh dorih zahalnoho korystuvannia, dilianok vulyts i dorih mist ta inshykh naselenykh punktiv, shcho sumishchaiutsia $\mathrm{z}$ avtomobilnymy dorohamy zahalnoho korystuvannia, v usikh oblastiakh ta m. Kyievi, a takozh dorozhnoi infrastruktury $\mathrm{u} \mathrm{m}$. Kyievi: Postanova Kabinetu Ministriv Ukrainy № 726 [About conducting an experiment on the financial support of the implementation of measures for the development of public highways, sections of streets and roads of cities and other settlements, which are combined with public highways, in all regions and Kyiv, as well as road infrastructure in the city Kyiv: Resolution of the Cabinet of Ministers of Ukraine No. 726]. (2015, September 16). Retrieved from https://zakon.rada.gov.ua/laws/show/726-2015-p [in Ukrainian].

2. Kontseptsiia reformuvannia mistsevoho samovriaduvannia ta terytorialnoi orhanizatsii vlady $\mathrm{V}$ Ukraini: rozporiadzhennia Kabinetu Ministriv Ukrainy № 333-p [The Concept of Reforming Local Self-Government and Territorial Organization of Government in Ukraine: Ordinance of the Cabinet of Ministers Ukraine No. 333-p]. (2014, April 01). Retrieved from https://zakon.rada.gov.ua/laws/show/333-2014-r [in Ukrainian].

3. Hoblyk, V. V., Artomov I. V. (Ed.). (2013). Mekhanizm stanovlennia zovnishnoekonomichnykh zviazkiv $\mathrm{u}$ transkordonnykh rehionakh $\mathrm{v}$ umovakh yevropeiskoi intehratsii Ukrainy[The mechanism of formation of foreign economic relations in cross-border regions in the conditions of European integration of Ukraine]. Modeli i mekhanizmy rehuliuvannia yevrorehionalnoho spivrobitnytstva Ukrainy: monohrafiia [Models and mechanisms of regulation of Euro-regional cooperation of Ukraine: monograph]. Uzhhorod, Hrazhda [in Ukrainian].

4. Zabarna, E. M. (2015). Instytutsiinyi faktor rozvytku rehionalnykh zovnishnoekonomichnykh zviazkiv v Ukraini [The institutional factor of development of regional foreign economic relations in Ukraine]. Ekonomika: realii chasu / Economics: The Realities of Time, 1 (17), pp. 30-34. Retrieved from http://economics.opu.ua/files/archive/2015/n1.html. [in Ukrainian]. 
5. Karpiak, M. O., Popadynets N. M. (2016). Zovnishnoekonomichna diialnist rehioniv Ukrainy $\mathrm{v}$ umovakh rosiiskoi ahresii: strukturni osoblyvosti [Foreign Economic Activity of the Regions of Ukraine in the Conditions of Russian Aggression: Structural Features]. Rehionalna ekonomika / Regional economy, 1, pp. 5158 [in Ukrainian].

6. Chernyshev, V. H., Okara D. V., Kovalova I. L. (2019). Zovnishnoekonomichna diialnist rehioniv Ukrainy [Foreign Economic Activity of the Regions of Ukraine]. Efektyvna ekonomika / Effective Economics, 6 [in Ukrainian]. doi: 10.32702/2307-2105-2019.6.53.

7. Alymov, O.M., Amosha, O. I. ta in., Liashenko, V. I. (Ed.). (2014). Pershyi etap modernizatsii ekonomiky Ukrainy: dosvid ta problemy [The first stage of modernization of Ukrainian economy: experience and problems]. Zaporizhzhia, KPU [in Ukrainian].

8. Amosha, O. I., Kharazishvili, Yu. M., Liashenko, V. I. ta in. (2018). Modernizatsiia ekonomiky promyslovykh rehioniv Ukrainy $\mathrm{v}$ umovakh detsentralizatsii upravlinnia [Modernization of economy of industrial regions of Ukraine in the conditions of decentralization of management]. Kyiv, Instytut ekonomiky promyslovosti [in Ukrainian].

9. Stratehiia staloho rozvytku «Ukraina - 2020»: Ukaz Prezydenta Ukrainy № 5/2015 [Sustainable Development Strategy «Ukraine-2020»: Presidential Decree No. 5/2015]. (2015, January 12). Retrieved from https://zakon.rada.gov.ua/laws/show/5/2015 [in Ukrainian].

10. Uhoda pro asotsiatsiiu mizh Ukrainoiu, $\mathrm{z}$ odniiei storony, ta Yevropeiskym Soiuzom, Yevropeiskym spivtovarystvom $\mathrm{z}$ atomnoi enerhii i yikhnimy derzhavamy-chlenamy, $\mathrm{z}$ inshoi storony: Zakon ukrainy № 1678-VII [Association Agreement between Ukraine, of the one part, and the European Union, the European Atomic Energy Community and their Member States, of the other part: Law of Ukraine No. 1678-VII]. (2014, September 16). Retrieved from https://zakon.rada. gov.ua/ laws/show/984_011 [in Ukrainian].

11. Lemdyaev, A. V. (2010). Konkurentosposobnost: regionalnyj vektor [Competitiveness: a regional vector]. Upravlenie ekonomicheskimi sistemami / Management of economic systems, 2 (22), pp. 54-58 [in Ukrainian].

12. Ofitsiinyi sait Derzhavnoi fiskalnoi sluzhby Ukrainy [Official site of the State Fiscal Service of Ukraine]. Retrieved from http://sfs.gov.ua [in Ukrainian].

13. Biletska, L. V., Biletskyi O. V., Savych V. I. (2009). Ekonomichna teoriia (Politekonomiia. Mikroekonomika. Makroekonomika) [Economic Theory (Political Economy. Microeconomics. Macroeconomics)]. Tutorial, 2nd edition. Kyiv, Tsentr uchbovoi literatury. Pp. 242-247 [in Ukrainian].

14. Trade and development report. United Nations (2002). Retrieved from https://unctad.org/en/Docs/ tdr2002_en.pdf.
Дятлова В. В., Положенцева К. В. Зовнішньоекономічна діяльність України: регіональні особливості, тенденції та напрями розвитку

У статті науково обгрунтовано сучасні особливості і тенденції у сфері зовнішньоекономічної діяльності економічних регіонів України за основними показниками. Встановлено, що три 3 дев'яти економічних регіонів є імпортоорієнтованими (Столичний, Карпатський, Північно-Західний), шість - експортоорієнтованими (Донецький, Придніпровський, Північно-Східний, Центральний, Подільський, Причорноморський). Однак експортний потенціал не реалізується в повному обсязі. Економічні регіони демонструють позитивні темпи приросту з 2016 року за імпортом і з 2017 року - за експортом. Найбільші темпи зростання імпорту відзначено в експортоорієнтованих регіонах. На цей час жоден регіон не досяг рівня базисного 2013 року за абсолютним приростом як з експорту, так і імпорту.

Проведено аналіз товарної структури експорту та імпорту за Стандартною міжнародною торговою класифікацією ЮНКТАД, згідно з якою 225 категорій товарів розподіляються на шість груп: А - основні продукти споживання, продукти харчування; В - трудомісткі і ресурсомісткі виробництва; С - виробництва 3 низьким рівнем кваліфікації і низькою технологічною інтенсивністю; D - виробництва з середнім рівнем кваліфікації і середньою технологічною інтенсивністю; Е - виробництва, що використовують висококваліфіковані трудові ресурси та які мають високий технологічний рівень; F - некласифіковані товари. Доведено, що в експорті більшості регіонів, за виключенням Донецького та Придніпровського, переважають сировинні товари категорії А 3 невеликою доданою вартістю, а також трудомісткі і ресурсомісткі категорії В, а в експорті - готові товари категорій B та D.

Запропоновано інструменти механізму розвитку економіки для відновлення статусу України як експортоорієнтованої держави, такі як розроблення та подальша реалізація за чіткими показниками Програм розвитку експорту за економічними регіонами; розроблення стратегії конкурентоспроможності України в глобальному світі, а на їі основі - конкретних програм за економічними регіонами, узгодженими з Програмами розвитку експорту; створення сприятливого інституціонального середовища для розвитку бізнесу, підтримка його конкурентних стратегій для формування певних конкурентних переваг для регіонального підприємництва; використання державно-приватного партнерства за певними програмами та бізнес-планами, націленими на зростання експортного потенціалу та імпортозаміщення. Реалізація інструментів на практиці сприятиме соціально-економічному розвитку регіонів і держави.

Ключові слова: зовнішньоекономічна діяльність; регіональні особливості; тенденції з експорту та імпорту; інструменти механізму розвитку економіки. 
Diatlova V., Polozhentseva K. Foreign Economic Activities of Ukraine: Regional Features, Trends and Directions for Development

The article substantiates modern peculiarities and tendencies in the sphere of foreign economic activity of economic regions of Ukraine according to the main indicators. It is established that three out of nine economic regions are import-oriented (Capital, Carpathian, Northwestern), six - are export-oriented (Donetsk, Pridneprovskyi, Northeastern, Central, Podilsky, Black Sea). However, the export potential is not fully realized. Economic regions have shown positive growth rates since 2016 in terms of imports and in 2017 in terms of exports. The highest growth rates of imports were observed in exportoriented regions. At this time, no region has reached the baseline level of 2013 in terms of absolute growth in both exports and imports.

The analysis of the commodity structure of exports and imports according to the Standard International Trade Classification UNCTAD, in compliance to which 225 categories of goods are divided into six groups: A - the main products of consumption, food; B - labour-intensive and resource-intensive production; $\mathrm{C}$ - production with low skills and low technology intensity; D - production with average skill level and average technological intensity; E productions that use highly skilled labour and have a high technological level; F - unclassified goods. It has been proven that in the export of most regions, with the exception of Donetsk and Pridneprovskyi regions, commodities of category A with low added value prevail, as well as labour-intensive and resource-intensive categories of $\mathrm{B}$, and finished goods of categories B and D dominate in import.

The instruments of the mechanism of economic development for restoring the status of Ukraine as an exportoriented state are offered, such as development and further implementation according to clear indicators of Export Development Programs by economic regions; development of a strategy of competitiveness of Ukraine in the global world, and on the basis of it - specific programs for economic regions, coordinated with export development Programs; creation of a favourable institutional environment for business development, support of its competitive strategies for the formation of certain competitive advantages for regional business; use of public-private partnership for specific programs and business plans aimed at increasing export potential and import substitution. The implementation of the instruments in practice will contribute to the socio-economic development of the regions and the state.

Keywords: foreign economic activity; regional peculiarities; trends in export and import; instruments of the mechanism of economic development.

Дятлова В. В., Положенцева Е. В. Внешнеэкономическая деятельность Украины: региональные особенности, тенденции и направления развития

В статье научно обоснованы современные особенности и тенденции в сфере внешнеэкономической деятельности экономических регионов Украины по основным показателям. Установлено, что три из девяти экономических регионов являются импортоориентированными (Столичный, Карпатский, Северо-Западный), шесть - экспортоориентированными (Донецкий, Приднепровский, Северо-Восточный, Центральный, Подольский, Причерноморский). Однако экспортный потенциал не реализуется в полном объеме. Экономические регионы демонстрируют положительные темпы прироста с 2016 года по импорту и с 2017 года по экспорту. Наибольшие темпы роста импорта отмечены в экспортоориентированных регионах. В настоящее время ни один регион не достиг уровня базисного 2013 года по абсолютному приросту как по экспорту, так и импорту.

Проведен анализ товарной структуры экспорта и импорта по Стандартной международной торговой классификации ЮНКТАД, согласно которой 225 категорий товаров делятся на шесть групп: А - основные продукты потребления, продукты питания; В - трудоемкие и ресурсоемкие производства; $\mathrm{C}$ - производства с низким уровнем квалификации и низкой технологической интенсивностью; D - производства со средним уровнем квалификации и средней технологической интенсивностью; Е - производства с высококвалифицированными трудовыми ресурсами и высоким технологическим уровнем; F - неклассифицированные товары. Доказано, что в экспорте большинства регионов, за исключением Донецкого и Приднепровского, преобладают сырьевые товары категории А с небольшой добавленной стоимостью, а также трудоемкие и ресурсоемкие категории В, а в экспорте - готовые товары категорий В и D.

Предложены инструменты механизма развития экономики для восстановления статуса Украины как экспортоориентированного государства, такие как разработка и последующая реализация по четким показателям Программ развития экспорта по экономическим регионам; разработка стратегии конкурентоспособности Украины в глобальном мире, а на ее основе - конкретных программ по экономическим регионам, согласованным с Программами развития экспорта; создание благоприятной институциональной среды для развития бизнеса, поддержка его конкурентных стратегий по формированию определенных конкурентных преимуществ для регионального предпринимательства; использования государственно-частного партнерства по определенным программам и бизнес-планами, нацеленными на рост экспортного потенциала и импортозамещение. Реализация инструментов на практике будет способствовать социально-экономическому развитию регионов и государства.

Ключевые слова: внешнеэкономическая деятельность, региональные особенности, тенденции по экспорту и импорту, инструменты механизма развития экономики.

Received by the editors: 10.12 .2019 and final form 19.12.2019 